\title{
BENAR ATAU SALAH?: PENGARUH MUSIK LATAR FILM TERHADAP EMOSI DAN PENILAIAN MORAL
}

\author{
Syuraswati Muhiddin \\ Magister Psikologi Sains, Fakultas Psikologi \\ Universitas Gadjah Mada, JI. Sosio Humaniora Bulaksumur, Daerah Istimewa Yogyakarta \\ Email: syurawasti.muhiddin@ugm.mail.ac.id
}

\begin{abstract}
Abstrak
Penelitian ini bertujuan untuk mengetahui pengaruh manipulasi musik latar terhadap emosi dan penilaian moral terhadap sebuah cuplikan adegan film. Penelitian ini merupakan replikasi penelitian eksperimen online Steffens (2018) dengan tujuan yang sama. Sebanyak 69 partisipan ditempatkan secara acak berdasarkan skor Moral Foundation Questionnaire, khususnya aspek Harm/Care ke dalam tiga kelompok (tanpa musik, musik negatif dan musik positif). Eksperimen dilakukan dengan media google form yang dikirimkan kepada partisipan melalui pesan WhatsApp. Hasil penelitian menunjukkan bahwa tidak ada pengaruh manipulasi jenis musik pada emosi yang dirasakan serta penilaian moral terhadap adegan film, kecuali pada partisipan yang menggunakan headphone. Pada kasus tersebut, terdapat perbedaan rileks dan reflektivitas (reflectiveness), yang diinduksi di antara tiga kelompok. Selanjutnya emosi yang dirasakan, yaitu agresi, keterhubungan, kebahagiaan, reflektivitas, sedih, dan tegang berhubungan dengan penilaian moral. Penelitian lebih lanjut dapat melihat efek mediasi dari reflectiveness dalam hubungan musik dan penilaian moral. Selain itu, hasil yang lebih signifikan dapat diperoleh dengan pelibatan partisipan yang lebih besar dalam setting eksperimen di luar jaringan, dengan kontrol terhadap beberapa variabel perancu yang terkait.
\end{abstract}

Kata Kunci: latar musik film, emosi, penilaian moral, eksperimen online

\section{"RIGHT OR WRONG?": \\ THE EFFECT OF FILM BACKGROUND MUSIC \\ ON EMOTION AND \\ MORAL JUDGEMENT}

\begin{abstract}
This study aimed to examine the effect of music background manipulation on emotion and moral judgments of a film scene. This study was a replication of Steffens' (2018) online experimental research with the same objectives. A total of 69 participants were randomly assigned based on Harm / Care aspect of the Moral Foundation Questionnaire score into three groups (without music, negative music and positive music). Experiment was conducted with a google form which was sent to participants via WhatsApp chat. The results showed that there was no effect of music manipulation on perceived emotions and moral judgments on film scenes, except for the participants who used headphones. In the case, there was a difference in relaxation and reflectiveness, which was induced among the three groups. Furthermore, the emotions felt, namely aggression, connectedness, happiness, reflectiveness, sadness, and tension were related to moral judgments. Further research could examine the mediating effect of reflectiveness in the relationship between music and moral judgment. Besides, more significant results can be inferred by including more participants in the offline experiment setting, with controlling several related confounding variables.
\end{abstract}

Keywords: film music background, emotion, moral judgement, online experiment 


\section{Pendahuluan}

Moralitas bukan hanya sekedar topik klasik dalam ilmu psikologi, melainkan juga sebuah konsep yang dekat dengan konsep kebermaknaan hidup. Moralitas memberikan seseorang perasaan bahwa dirinya adalah manusia yang layak (Pinker, 2008 dalam Avise \& Ayala, 2010). Secara sosiologis, moralitas penting dalam mendukung kehidupan sosial. Dalam pandangan psikologi, moral berkaitan dengan reputasi dan kecaman sosial, yaitu sejauh mana orang-orang peduli pada pikiran orang lain terhadapnya. Selain itu, moral berkaitan dengan kepedulian seseorang untuk melakukan hal yang benar; dalam hal ini menunjukkan hati nurani (Pecorino, 2006).

Berhubungan dengan hal tersebut, manusia pada dasarnya memiliki sifat prososial yang dipertimbangkan sebagai moralitas yang baik. Sejumlah eksperimen sosial-ekonomi menunjukkan bahwa beberapa orang dapat bertindak prososial bahkan dalam interaksi yang anonim sekalipun, baik ketika ada maupun tidak ada keuntungan langsung yang diperoleh (Camerer, 2011 dalam Capraro dkk., 2021). Kerangka moral yang terbentuk dapat berasal dari preferensi moral yang diinternalisasi secara mendalam dan tidak begitu dipengaruhi oleh pengamatan orang lain (Capraro dkk., 2021). Dengan demikian, seseorang dapat tetap menunjukkan moralitas meskipun tidak ada orang lain yang menontonnya ataupun menyuruhnya.

Dari penjelasan di atas dapat dipahami bahwa moralitas adalah bagian dari kemanusiaan dan merupakan hal penting untuk mendukung kesejahteraan suatu masyarakat. Meskipun demikian, manusia masih menghadapi tantangan-tantangan seperti ketidaksetaraan sosial dan ekonomi, serta penipisan sumber daya (Capraro dkk., 2021). Faktor penyebab tidak bisa sepenuhnya dikaitkan dengan moralitas manusia. Namun penilaian moral manusia terhadap suatu tindakan dapat menentukan keputusannya dalam kehidupan sehari-hari, yang kemudian memberikan dampak jangka panjang.

Bagaimana orang lain membentuk penilaian moral yang diketahui bukan merupakan realitas objektif? Ketika diperhadapkan pada tindakan orang lain, seseorang memikirkan terlebih dahulu perilaku tersebut untuk memberikan penilaian lebih lanjut mengenai benar atau salahnya tingkah laku orang tersebut. Namun, terkadang ada situasi di mana seseorang segera tahu bahwa ada sesuatu yang benar atau salah dan sebagai akibatnya, seseorang merasa baik atau buruk tentang hal itu, tanpa pertimbangan sadar sebelumnya. Berkaitan dengan penilaian moral tersebut, para peneliti telah mendeskripsikan dua tipe penilaian moral: dikendalikan secara sadar dan disengaja, serta otomatisintuitif (Critcher dkk., 2020; Cushman dkk., 2010).

Penilaian moral dapat diartikan sebagai evaluasi penerimaan moral atas tindakan sendiri dan tindakan orang lain (Szekely \& Miu, 2015). Dalam waktu yang lama, dasar penilaian moral didominasi oleh pendekatan rasional (seperti Piaget, 1965; Kohlberg, 1969). Hal ini yang juga diharapkan dapat menghasilkan penilaian objektif. Meskipun demikian, semakin banyak bukti yang menunjukkan besarnya peran kritis emosi dalam proses tersebut (Avramova \& Inbar, 2013; Greene \& Haidt, 2002). Dalam model Greene's Dual Process (Cushman dkk., 2010), penilaian moral akhir adalah hasil interaksi antara emosi dan penalaran (refleksi kognitif), sedangkan dalam model Social Intuitionist (Haidt, 2001) prosesnya terutama ditentukan oleh emosi. Mendukung keterlibatan emosi, Hume (dalam Haidt, 2001) berpendapat bahwa pengetahuan moral tidak berasal dari rantai argumen dan kesimpulan, tetapi dari perasaan langsung dan rasa moral batin.

Selain Model Social Intuitionist, Haidt dan Graham (2007) mengembangkan Moral Foundation Theory (MFT). MFT mengusulkan bahwa pikiran manusia telah diatur sebelum pengalamannya 
sehingga siap untuk mempelajari nilai-nilai, norma, dan perilaku yang terkait dengan beragam tantangan sosial adaptif yang berulang. Banyaknya tantangan ini melahirkan banyak fondasi moral. MFT mengusulkan lima fondasi awal yang berbeda, yaitu in-group/loyalitas, otoritas/rasa hormat, menyakiti/kepedulian, keadilan/resiprokal, dan kemurnian/kesucian; kelimanya dianggap sebagai dasar dari penilaian moral. Haidt dan Graham (2007) mengusulkan adanya hubungan spesifik antara fondasi moral tersebut dengan emosi yang berbeda. Misalnya, bahaya/kepedulian melibatkan emosi yang berhubungan dengan penghindaran upaya menyakiti orang lain, seperti simpati dan kasih sayang. Meskipun demikian, hubungan antara fondasi moral dan emosi yang berbeda tersebut belum konsisten dan hanya pada emosi tertentu saja (Haidt \& Graham, 2007; Steffens, 2018) sehingga diperlukan penelitian lanjut untuk meningkatkan bukti empiris.

Literatur tentang regulai emosi menunjukkan bahwa seseorang tidak secara pasif dipengaruhi oleh emosi (Zhang dkk., 2017). Mereka dapat menggunakan strategi yang berbeda untuk mengatur emosi mereka (Gross, 2013). Beberapa penelitian menelaah hubungan antara strategi regulasi emosi dengan penilaian moral dan pengambilan keputusan. Feinberg, Willer, Antonenko, dan John (2012) menemukan bahwa penilaian kembali yang menunjukkan adanya regulasi emosi mengarah kepada penilaian moral yang lebih disengaja. Szekely dan Miu (2015) menemukan bahwa penilaian kembali secara negatif dapat memprediksi pilihan deontologis, yaitu "menolak untuk menyakiti orang lain, terlepas dari semua konsekuensi yang diperolehnya." Namun, Lee dan Gino (2015) menemukan bahwa penilaian kembali tidak memiliki hubungan dengan pilihan moral, sementara tekanan atau pemaksaaan dapat menghasilkan pilihan yang lebih bermanfaat. Hasil yang berbeda dapat berkaitan dengan kerangka moral yang berbeda, juga fondasi moral yang berbeda yang digunakan sebagai dasar membuat penilaian.

Pada kenyataannya, regulasi emosi yang buruk dapat berkaitan dengan penilaian moral yang keliru. Regulasi emosi yang buruk dapat ditandai dengan menurunnya beberapa indikator, yaitu: kesadaran dan pemahaman emosi; penerimaan emosi; kemampuan untuk terlibat dalam perilaku yang diarahkan pada tujuan, dan menahan diri dari perilaku impulsif ketika mengalami emosi negatif; serta akses menuju strategi regulasi yang efektif. Zhang, Kong dan Li (2017) menemukan bahwa kesulitan regulasi emosional dapat secara signifikan memprediksi penilaian amoralitas pada lima domain fondasi moral. Selain itu, valensi emosional dan gairah memediasi efek dalam domain bahaya, keadilan dan kesucian. Oleh karena itu, mengatur emosi menjadi hal yang dapat diperhatikan dalam rangka membuat penilaian moral.

\section{Musik Film dan Emosi}

Musik telah menjadi bagian dari gaya hidup manusia. Telaah terhadap sejumlah penelitian menunjukkan bahwa musik dapat digunakan untuk memunculkan emosi tertentu pada manusia (Juslin \& Laukka, 2004). Sejumlah emosi tertentu seperti kebahagiaan, kesedihan, kemarahan, takut, dan kelembutan dikorelasikan dengan tipe musik tertentu sehingga emosi sangat terkait dengan motif utama kebanyakan orang untuk mendengarkan musik tertentu (Juslin \& Laukka, 2004). Musik latar dapat meningkatkan evaluasi positif individu terhadap lingkungan dan meningkatkan kesenangan dan dominasi emosi (Yi \& Kang, 2019). Meskipun demikian, tidak semua modulasi musik latar belakang dapat memunculkan emosi tertentu yang diharapkan muncul dan justru memunculkan jenis emosi lain (Pavlovic \& Markovic, 2011).

Kekuatan musik dalam memunculkan emosi dapat terjadi dalam berbagai konteks, termasuk film, 
yaitu menggunakan latar belakang musik film. Musik film memiliki kemampuan untuk memengaruhi emosi pendengar (Bullerjahn dalam Steffens, 2018) dan dapat dianggap sebagai sumber emosi kedua selain film itu sendiri (Cohen, 2001). Cohen (dalam Cohen, 2001) mengidentifikasi fungsi musik film yang melibatkan emosi, yaitu membantu menciptakan keberlanjutan narasi/cerita; memberikan makna emosional terhadap kejadian dalam film; induksi suasana hati; menciptakan dan mengaktivasi memori tertentu; mempertahankan gairah, atensi, dan rasa terkait realitas; serta pengalaman estetik. Lebih lanjut Vinovich (dalam Steffens, 2018) mengungkapkan bahwa musik dapat mendorong kutipan film netral ke arah emosi tertentu. Pada dasarnya sountrack film dapat mengkomunikasikan makna film tersebut (Cohen, 2001)

Pengaruh musik pada interpretasi penonton dan penilaian film telah ditunjukkan dalam beberapa percobaan. Hoeckner, Wyatt, Decety dan Nusbaum (dalam Lipscomb \& Tolchinsky, 2005) menunjukkan bahwa musik film dapat mempengaruhi disukainya karakter dan kepastian mengetahui pikiran karakter. Bullerjahn \& Güldenring (dalam Steffens, 2018) mengamati bahwa interpretasi kutipan film berdurasi 10 menit dipengaruhi oleh emosi yang dirasakan terkait adanya musik film. Misalnya, penggunaan musik thriller, membuat peserta berpikir pemeran protagonis mempunyai niat kriminal. Penonton juga melakukan antisipasi tentang pengembangan lebih lanjut dari urutan cerita secara sistematis karena dipengaruhi oleh musik film yang mendasarinya (Vitouch, 2016).

\section{Musik Latar dan Penilaian Moral}

Beberapa penelitian menunjukkan bahwa musik latar secara umum dapat mempengaruhi penilaian moral. Dalam konteks interpersonal, penelitian Greitemayer (2009) menunjukkan bahwa musik dengan lirik prososial meningkatkan pemikiran pro-sosial dan menyebabkan lebih banyak empati antarpribadi yang dirasakan, sedangkan lirik lagu yang agresif secara seksual memunculkan pikiran, emosi, dan perilaku yang agresif (Fischer \& Greitemeyer, 2006). Sejalan dengan temuan itu, penelitian Brodsky, Olivieri, dan Chekaluk (2018) menunjukkan bahwa musik yang energik meningkatkan kegembiraan pengemudi, sementara itu musik yang tidak ramah dengan konten kekerasan menunjukkan peningkatan kecepatan jelajah dan persentase waktu yang melebihi batas kecepatan. Selain itu, Ziv, Hoftman dan Geyer (2012) meneliti pengaruh musik latar terhadap kemampuan mengingat dan evaluasi iklan radio yang mempromosikan berbagai jenis kecurangan dan menemukan bahwa musik dapat memanipulasi dan menyebabkan bias penilaian moral. Musik dengan valensi positif mengurangi kesadaran akan pesan yang tidak etik dan meningkatkan penerimaan produk (Ziv dkk., 2012). Temuan Seidel \& Prinz (2013b) juga mendukung bahwa kemarahan yang dimunculkan oleh efek musik (bukan musik bahagia) dapat meningkatkan kecenderungan untuk menilai tindakan sebagai sesuatu yang salah dan dapat memperkuat penilaian moral atas pelanggaran otonomi seperti menipu (Seidel \& Prinz, 2013); sementara itu kebahagiaan yang diinduksi oleh musik meningkatkan kecenderungan untuk menilai tindakan sebagai hal yang baik dan wajib (Seidel \& Prinz, 2013a). Steffens (2018) juga menemukan bahwa musik positif mempengaruhi kebahagiaan dan secara tidak langsung (melalui emosi tersebut) mempengaruhi penilaian moral. Secara umum, Palazzi, Fritzen, dan Gauer (2019) dari hasil telaah sistematisnya terhadap beberapa riset terkait menemukan bahwa musik adalah rangsangan yang kuat dan menarik yang dapat memengaruhi proses pengambilan keputusan dan pengambilan risiko, mempromosikan sikap ataupun tindakan pro-sosial, dan memengaruhi pilihan perilaku pelanggan.

Meskipun demikian, terdapat juga penelitian lain yang tidak dapat menunjukkan efek dari 
manipulasi musik, khususnya dalam konteks film. Hasil studi oleh Brosius tahun 1990 tentang efek musik latar terhadap memori dan evaluasi informasi dalam film tidak dapat direplikasi hasilnya oleh Kopiez, Platz dan Wolf (2013). Penjelasan potensial untuk efek nol ini adalah hipotesis habituasi Behne pada 1999 yang menyatakan bahwa efek musik latar telah terus menurun karena pertumbuhan dan ketersediaan musik yang semakin meningkat dalam kehidupan sehari-hari. Dalam meta-analisisnya, Behne (dalam Steffens, 2018) mengamati bahwa efek musik pada emosi, persepsi dan perilaku telah menurun sebesar 8\% per dekade. Penelitian Beer dan Greitemeyer (2019) terkait dengan musik dan perilaku sosial menunjukkan bahwa perilaku memberi tip oleh tamu yang lebih muda tidak dipengaruhi oleh latar musik dengan genre apapun, sementara itu tamu yang lebih tua tampak lebih banyak memberikan tip saat diperdengarkan musik yang membangkitkan semangat dan melankolis dibandingkan dengan musik netral. Sebuah meta-analisis yang dilakukan oleh Kämpfe, Sedlmeier \& Renkewitz (2011) menemukan tidak adanya efek musik dari analisis umum, namun pemeriksaan terperinci terhadap studi yang ada menunjukkan bahwa efek nol ini dapat disebabkan oleh rata-rata ukuran efek tertentu. Probabilitas mendeteksi efek spesifik tersebut tidak terlalu besar karena kurangnya studi terkait hal tersebut. Tetap ada beberapa kasus yang menunjukkan adanya pengaruh musik latar (dibandingkan dengan tidak adanya musik latar) termasuk pada reaksi emosi. Disarankan untuk melakukan upaya yang lebih terkontrol dan relevan untuk meningkatkan kualitas metodologi (Kämpfe dkk., 2011). Penelitian terbaru Steffens (2018) yang mengaitkan penilaian moral dan latar musik, meskipun signifikan pada satu kasus (dari 3 kasus), namun tidak pada ketiganya.

Dengan demikian, dari penjelasan sebelumnya dapat disimpulkan bahwa efek musik terhadap evaluasi film belum sepenuhnya menunjukkan hasil yang konsisten. Terkhusus, hasil yang menunjukkan pengaruh musik latar terhadap evaluasi moral tindakan dalam konteks film layar lebar. Penelitian Steffens (2018) adalah salah satu penelitian eksperimen yang relatif baru; menelaah tentang pengaruh potensial musik latar belakang film terhadap emosi yang dirasakan dan penilaian moral. Penelitian eksperimen ini mereplikasi penelitian Steffens tersebut dari segi unit dan atau kriteria subjek, variabel yang diukur, serta setting. Perubahan dilakukan pada level perlakuan dan teknis pelaksanaan eksperimen.

Terdapat beberapa pertimbangan yang mendasari replikasi ini. Dalam konteks Indonesia, belum ada penelitian yang secara khusus mengaitkan musik latar belakang film dengan penilaian moral sebagai penelitian psikologi. Sebuah penelitian dengan sampel orang Indonesia yang baru-baru dipublikasikan menunjukkan adanya hubungan emosi yang berbeda terhadap standar ganda dan penilaian etik pada konsumen (Septianto dkk., 2020). Namun penelitian ini menitikberatkan pada emosi dan perilaku konsumen, bukan musik latar belakang yang memunculkan emosi serta penilaian moralnya. Adanya indikasi bahwa musik memainkan peranan dalam memicu agresivitas dan mempengaruhi penilaian moral hingga pada akhirnya tindakan-tindakan seseorang melalui film, membuatnya menarik untuk ditelaah lebih lanjut. Selain itu, penelitian ini merupakan penelitian eksperimen yang dilakukan secara online sehingga merupakan inovasi metode eksperimen yang dapat dikembangkan di tengah situasi pembatasan sosial di masa pandemik.

Dengan mengacu pada penelitian asli, penelitian ini bertujuan untuk mengetahui pengaruh musik latar film pada emosi dan penilaian moral terhadap suatu adegan dalam film. Pada penelitian ini dirumuskan tiga hipotesis: 1) H1, ada perbedaan emosi yang muncul dipengaruhi manipulasi latar belakang musik pada cuplikan kutipan film; 2) H2, ada pengaruh latar belakang musik film terhadap penilaian moral.; 3) $\mathrm{H} 3$, ada hubungan emosi tertentu yang dirasakan dengan penilaian moral terhadap 
tindakan yang digambarkan dalam film.

\section{Metode}

\section{Partisipan}

Sebanyak 71 orang mendaftarkan diri sebagai partisipan dalam call for participants yang disebarkan melalui media sosial. Kriteria inklusi partisipan adalah minimal lulus sekolah menengah atas/sederajat, berusia 21-48 tahun (dewasa awal dan tengah), memiliki HP dan dapat mengakses internet. Pemilihan usia partisipan didasarkan pertimbangan bahwa pada usia tersebut seorang individu telah memasuki tahap penalaran moral tingkat akhir berdasarkan teori Kohlberg, yaitu adanya kesadaran akan orientasi hukum dan legalitas serta prinsip etika universal. Partisipan di bawah usia 21 tahun serta yang memiliki gangguan pendengaran dan penglihatan merupakan kriteria ekslusi. Pengumpulan data dilakukan secara online (daring) sebagaimana eksperimen asli yang dilakukan Steffens (2018) selama lima hari pada pekan ketiga April 2020. Instrumen survei yang digunakan adalah google form, baik pada pendaftaran calon partisipan maupun pada proses pelaksananaan penelitian.

Sebanyak 69 partisipan dari pendaftar yang memenuhi responden ditempatkan secara acak ke dalam tiga kelompok (kelompok tanpa musik/1A, kelompok musik negatif/1B, kelompok musik positif/1C). Partisipan terdiri atas $68,1 \%(n=47)$ perempuan dan 31,9\% $(n=22)$ laki-laki. Usia responden umumnya berkisar antara $21-34$ tahun, yaitu sebanyak $83 \%$ (57 orang), selebihnya adalah partisipan yang berusia $35-48$ tahun (17\%). Rata-rata usia partisipan adalah 28,15 (SD = 6,0). Pekerjaan partisipan bervariasi, yaitu mahasiswa $(33,3 \%)$, karyawan swasta $(20,2 \%)$, Aparatur Sipil Negara dan wiraswasta $(11,6 \%)$, pendidik $(10.1 \%)$, ibu rumah tangga $(4,3 \%)$, tenaga medis dan belum bekerja $(2,9 \%)$, sisanya adalah polisi dan juga tidak menjawab (1,4\%). Sebagian besar partisipan telah menyelesaikan pendidikan S1 (71\%); sebanyak $17,4 \%$ telah menyelesaikan pendidikan SMA; dan masing-masing 4 orang $(5,8 \%)$ yang menyelesaikan D1 dan S2. Dari keseluruhan partisipan, hanya 11 orang $(17,5 \%)$ yang mengetahui cuplikan film yang ditayangkan, sementara 52 sisanya $(82,5 \%)$ tidak mengetahui.

\section{Material}

Film dan musik yang digunakan dalam penelitian ini berbeda dengan penelitian asli yang menggunakan dua cuplikan film. Penelitian ini hanya menggunakan satu cuplikan film, yaitu Marlina si Pembunuh dalam Empat Babak (2017). Film ini merupakan film produksi Indonesia yang berkisah tentang seorang janda yang tinggal sendiri di sebuah padang sabana di Sumba; rumahnya didatangi oleh sekelompok perampok berjumlah 7 orang yang mengambil semua ternaknya dan mengancam nyawa serta kehormatannya di hadapan mayat suaminya yang berbentuk mumi (belum sempat dikuburkan berdasarkan adat Sumba), duduk di pojok ruangan makan. Untuk menyelamatkan dirinya, Marlina memberikan racun pada makanan para perampok yang dia masak. Adegan yang dipilih dari film juga merupakan adegan ketika Marlina menghidangkan makanan kepada perampok hingga perampok tersebut berjatuhan karena mengonsumsi racun. Adegan ini dianggap bersifat ambigu (tidak jelas) untuk menilai tindakan benar atau salah dan tidak terdapat musik latar dalam film aslinya sehingga peneliti bisa memasukkan instrumen musik yang dianggap dapat memunculkan emosi positif dan negatif, yang kemudian mempengaruhi penilaian moral (hal ini juga menjadi pertimbangan Steffens dalam eksperimen asli). Film ini dipilih setelah sebelumnya dilakukan survei dalam skala kecil di kalangan rekan peneliti sesama lulusan psikologi untuk menyebutkan film yang dapat memunculkan penilaian ambigu, yaitu antara benar atau salah, lalu mendiskusikannya lebih lanjut. Film yang dipilih 
ini dapat menimbulkan penilaian moral terkait dengan upaya membunuh untuk menyelamatkan diri.

Sementara itu, terdapat dua jenis musik instrumen yang dipilih. Pemilihan musik dilakukan melalui diskusi dengan salah satu peneliti yang memiliki latar belakang pendidikan seni musik. Instrumen musik yang diharapkan memunculkan emosi negatif (agresi, kemarahan dan ketegangan), yaitu instrumen yang memiliki tempo cepat dan menimbulkan tekanan, berjudul Dramatic Suspenseful Tense Ambiance. Sedangkan, instrumen musik yang diharapkan memunculkan emosi positif (bahagia, rileks, damai) adalah instrumen yang bertempo pelan atau lembut dan melankolis, berjudul Mimetics. Durasi musik yang dimasukkan dalam video masing-masing sekitar satu menit di akhir cuplikan. Durasi cuplikan film sendiri masing-masing 2 menit 16 detik. Cuplikan film tersebut juga ditambahkan deskripsi singkat (2 kalimat) sebagai pengantar di dalam formulir. Deskripsi tersebut dibuat senetral mungkin agar tidak mempengaruhi kecenderungan pilihan partisipan. Pemberian deskripsi ini merupakan modifikasi dari perlakuan karena tidak diberikan dalam eksperimen asli yang dimaksudkan untuk menyamakan pengetahuan awal partisipan terkait cuplikan film.

\section{Pengukuran}

Instrumen pengukuran hasil pada eksperimen ini menggunakan instrumen yang sama dengan eksperimen asli, yaitu berupa rating scale terhadap sepuluh jenis emosi yang mungkin diinduksi dan sebuah pertanyaan tentang pilihan benar/salah (lampiran). Pemilihan emosi didasarkan pada literatur serta karakteristik stimulus yang diberikan. Daftar emosi yang diukur dapat dilihat pada Tabel 1. Tidak ada pertanyaan terkait dengan musik film yang diberikan untuk menghindari adanya perhatian pada manipulasi eksperimen (Steffens, 2018). Uji coba instrumen google form (pilot study) dilakukan pada 12 orang selain partisipan.

Selain itu, dilakukan pula pengukuran fondasi moral kepada partisipan yang mendaftar dengan menggunakan Moral Foundation Questionnaire (MFQ) - 30 (Graham dkk., 2011) versi terjemahan bahasa Indonesia dari https://moralfoundations.org/. Fondasi moral merujuk pada suatu sistem psikologis bawaan dan bersifat universal yang merupakan dasar dari etika intuitif, termasuk dalam menilai moralitas tindakan. Hal ini berarti bahwa setiap orang memiliki fondasi moral ini. MFQ-30 ini membedakan antara lima faktor yang menjadi dasar dalam penilaian moral. Reliabilitas (Cronbach's $\alpha$ ) dari kelima faktor yang diukur melalui penelitian ini adalah 0,63 untuk Care/Harm, 0,67 untuk Fairness/Reciprocity, 0,64 untuk In-Group/Loyalty, 0,59 untuk Authority/Respect dan Purity/Sanctity. Skor dari Faktor Care/Harm dari MFQ digunakan sebagai dasar randominasi. Fondasi moral ini terkait dengan evolusi panjang manusia dengan sistem kelekatan dan kemampuan merasakan (ataupun tidak menyukai) rasa sakit orang lain; mendasari kebajikan seperti tindakan pro sosial, kelembutan dan pemeliharaan (Graham dkk., 2011). Faktor ini yang dianggap berkaitan dengan emosi-emosi yang diinduksi ketika diperhadapkan pada suatu tindakan. Dengan mengukur fondasi moral, variabel ini dapat dikontrol, yaitu dengan menyebarkan individu dengan fondasi moral aspek Harm/Care yang tinggi, sedang, dan rendah secara merata ke semua kelompok eksperimen.

Selanjutnya, dilihat juga jenis pengaturan audio yang digunakan oleh para peserta yang diasumsikan akan berpengaruh pada stimulasi emosi yang dirasakan. Partisipan ditanya mengenai jenis perangkat audio yang digunakan untuk membedakan antara penggunaan headphone/headset, earphone/handsfree, dan pengeras suara internal laptop/smartphone/ tablet (tanpa menggunakan perangkat audio). 
Tabel 1. Jenis Emosi yang Dapat Dipicu dari Cuplikan Film

\begin{tabular}{|c|c|}
\hline Emosi & Pemicu non-musik yang potensial \\
\hline Agresi & $\begin{array}{l}\text { Perilaku sekelompok perampok terhadap janda ketika disajikan } \\
\text { makanan }\end{array}$ \\
\hline Marah & $\begin{array}{l}\text { Perilaku perampok dan perilaku Janda (kesalahan moral dari } \\
\text { tindakan) }\end{array}$ \\
\hline $\begin{array}{l}\text { Keterhubung } \\
\text { an }\end{array}$ & Merasa terhubung dengan perasaan Janda \\
\hline Ketakutan & $\begin{array}{l}\text { Menyaksikan perampok disajikan makanan, janda meracuni } \\
\text { perampok }\end{array}$ \\
\hline Kebahagiaan & $\begin{array}{l}\text { Janda berhasil terbebas dari perampok, perampok terbunuh, } \\
\text { janda tersenyum }\end{array}$ \\
\hline Kedamaian & Janda berhasil meracuni perampok, perampok terbunuh \\
\hline Rileks & Janda berhasil terbebas dari perampok, janda tersenyum. \\
\hline Reflektivitas & Pertimbangan moral tentang kebenaran tindakan \\
\hline Sedih & Kehidupan janda dan perlakuan perampok \\
\hline Tegang & Perilaku perampok dan janda yang meracuni mereka. \\
\hline
\end{tabular}

\section{Prosedur}

Secara garis besar, prosedur eksperimen mengikuti prosedur dalam penelitian Steffens (2018) dengan penyesuaian teknis tertentu. Peneliti membuka kesempatan bagi yang ingin berpartisipasi secara sukarela dalam eksperimen online ini dengan mengisi link pendaftaran (http://ugm.id/EXP3). Partisipan mengisi data jenis kelamin, usia, pendidikan terakhir, pekerjaan, nomor akun WhatsApp, ketersediaan akses internet, jenis perangkat audio yang dimiliki, gangguan penglihatan/pendengaran jika ada, serta skala MFQ-30. Partisipan juga menyatakan kesediaannya melalui formulir. Partisipan yang memenuhi syarat dikelompokkan secara acak ke dalam tiga kelompok (tanpa musik/1A, musik negatif/1B, musik positif/1C) dengan berdasarkan skor MFQ-30 aspek Care/Harm. Skor tinggi, sedang, dan rendah berdasarkan penormaan kelompok, ditempatkan secara merata ke dalam tiga kelompok secara acak dengan menggunakan https://www.randomlists.com/team-generator. Masing-masing kelompok terdiri dari 23 partisipan. Untuk menjalankan proses eksperimen, semua partisipan dihubungi melalui pesan teks WhatsApp secara personal oleh masing-masing peneliti. Peneliti memberikan pengantar tentang studi, termasuk jaminan kerahasiaan data. Selanjutnya partisipan diberikan instruksi untuk diikuti, termasuk link untuk akses google form (lampiran). Peserta dianjurkan menggunakan headphone/headset saat mendengarkan tayangan terutama untuk kelompok 1B dan 1C. Partisipan diminta untuk mengkonfirmasi apabila telah selesai menonton cuplikan dan mengisi kuesionernya. Di akhir kuesioner tersebut, partisipan ditanyakan mengenai jenis perangkat audio yang digunakan. Setelah mengisi link, peneliti menyampaikan tujuan penelitian (debriefing), mengucapkan terima kasih dan menyampaikan informasi undian reward. Peneliti menghubungi lebih lanjut lima partisipan yang memenangkan hadiah. 


\section{Analisis}

Data dianalisis dengan analisis statistisk non-parametrik dikarenakan jumlah sampel relatif kecil di setiap kelompok $(\mathrm{n}<30$ ). Lebih dari itu, data beberapa kelompok tidak terdistribusi normal dan tidak memenuhi asumsi homogenitas. Hipotesis pertama diuji dengan menggunakan uji Kruskall-Wallis untuk membedakan ketiga kelompok dalam rangka melihat kemungkinan pengaruh pemberian musik terhadap emosi. Uji Mann-Whitney digunakan untuk membandingkan dua kelompok (kelompok $1 \mathrm{~A}$ dengan $1 \mathrm{~B} ; 1 \mathrm{~A}$ dengan $1 \mathrm{C}$; serta $1 \mathrm{~B}$ dan $1 \mathrm{C})$. Hipotesis kedua juga diuji dengan langkah pengujian yang sama untuk menelaah perbedaan penilaian moral dari ketiga kelompok. Selanjutnya, hipotesis ketiga diuji dengan uji korelasi Spearman Ranks. Analisis lanjutan dilihat untuk menelaah kemungkinan hubungan antara Fondasi Moral dengan emosi dan penilaian moral (uji korelasi Spearman Ranks). Semua analisis statistik menggunakan bantuan IBM SPPS 20.0 dan level signifikansi diatur pada $\alpha=$ 0.05 .

\section{Hasil}

\section{Statistik Deskriptif}

Tabel 2 menunjukkan rata-rata penilaian moral dan emosi yang dilaporkan dengan standar deviasinya. Dapat dilihat bahwa rata-rata penilaian moral serta sebagian besar peringkat emosi tergolong agak rendah. Selain itu, tidak ada perbedaan yang besar di antara rata-rata emosi yang dilaporkan dari ketiga kelompok, begitu juga dengan penilaian moral. Terlihat bahwa rata-rata skor penilaian moral kelompok $1 \mathrm{C}$ lebih besar di antara kedua kelompok lainnya yang dapat menunjukkan adanya kecenderungan membenarkan tindakan protagonis dalam membunuh.

\section{Pengujian Hipotesis}

\section{Hipotesis I}

Hipotesis pertama mengasumsikan pengaruh musik terhadap emosi yang diinduksi dalam eksperimen. Hasil uji terhadap tiga kelompok menunjukkan tidak adanya perbedaan semua jenis emosi yang ditanyakan ( $p>0.05$ ). Pengujian kemudian dilakukan antara kelompok tanpa musik (1A) dengan kelompok musik baik negatif (1B) maupun positif (1C), khusus pada emosi yang kemungkinan diinduksi oleh kedua jenis musik: musik negatif yang dapat menimbulkan agresi, marah dan tegang, lalu musik positif yang dapat menimbulkan kebahagiaan, kedamaian dan rileks. Hasil pengujuan menunjukkan tidak adanya perbedaan emosi yang dimaksud tersebut antara kelompok $1 \mathrm{~A}$ dan $1 \mathrm{~B}$ serta kelompok $1 A$ dan $1 C$ ( $p>0.05)$. Pengujian juga dilakukan antara kelompok dengan musik negatif dan musik positif (1B dan 1C) untuk membedakan emosi yang kemungkinan diinduksi oleh kedua jenis musik tersebut (disebutkan sebelumnya). Hasil pengujian juga tidak signifikan ( $p>0.05)$. Semua pengujian menunjukkan bahwa manipulasi musik tidak berpengaruh terhadap jenis emosi yang dirasakan pada eksperimen ini. Cukup sejalan dengan hasil uji pertama terhadap hipotesis 1 dalam eksperimen Steffens (2018) yang menunjukkan tidak adanya pengaruh.

Selain itu, pengujian eksperimen ini juga dilakukan khusus kepada peserta yang menggunakan headphone ( $\mathrm{n}=14$ ) untuk mengeksplorasi efek potensial dari peralatan yang digunakan. Langkah ini juga dilakukan oleh Steffens (2018) pada eksperimennya. Pengujian dilakukan terhadap tiga kelompok ( $\mathrm{n}$ $1 \mathrm{~A}=4 ; \mathrm{n} 1 \mathrm{~B}=4 ; \mathrm{n} 1 \mathrm{C}=6$ ) yang menunjukkan bahwa terdapat perbedaan emosi, yaitu rileks dan reflektivitas (reflectiveness), yang berarti manipulasi musik dapat mempengaruhi rileks dan reflectiveness pada partisipan yang menggunakan headphone $(p<0.05)$. Hal ini cukup berbeda dengan hasil 
eksperimen asli yang menunjukkan tidak adanya pengaruh musik terhadap jenis emosi pada partisipan yang menggunakan headphone.

Hipotesis II

Hipotesis dua mengasumsikan pengaruh manipulasi musik terhadap penilaian moral. Dilakukan empat kali pengujian; satu kali pengujian terhadap ketiga kelompok dan tiga kali pengujian terhadap dua kelompok (kelompok 1A dan 1B; kelompok $1 \mathrm{~A}$ dan 1C, serta kelompok 1B dan 1C). Semua pengujian menunjukkan hasil yang tidak signifikan ( $p>0.05$ ). Sama halnya dengan pengujian hipotesis pertama, untuk mengeksplorasi efek potensial dari peralatan yang digunakan, analisis terpisah dilakukan untuk peserta yang menggunakan headphone selama percobaan $(n=14)$. Pengujian menunjukkan hasil yang signifikan $(p<0.05)$ yang berarti bahwa manipulasi musik positif dan negatif membedakan kebenaran tindakan yang dipersepsikan atau penilaian moral.

Tabel 2. Mean dan Standar Deviasi Penilaian Moral dan Emosi yang Dilaporkan

\begin{tabular}{lcccccc}
\multicolumn{1}{c}{ Kondisi } & \multicolumn{2}{c}{$\begin{array}{c}\text { Tidak Ada Musik } \\
\text { (1A) }\end{array}$} & \multicolumn{2}{c}{$\begin{array}{c}\text { Musik Negatif } \\
\text { (1B) }\end{array}$} & \multicolumn{2}{c}{$\begin{array}{c}\text { Musik Positif } \\
\text { (1C) }\end{array}$} \\
& Mean & (SD) & Mean & (SD) & Mean & (SD) \\
$\begin{array}{l}\text { Penilaian } \\
\begin{array}{l}\text { Moral/Kebenaran } \\
\text { tindakan }\end{array}\end{array}$ & $\mathbf{4 , 0 4}$ & $\mathbf{( 1 , 9 9 )}$ & $\mathbf{4 , 4 7}$ & $\mathbf{1 , 9 9}$ & $\mathbf{4 , 6 6}$ & $\mathbf{( 1 , 8 3 )}$ \\
Emosi & & & & & & \\
Agresi & & & & & & \\
Marah & 3.78 & $(1.90)$ & 2,86 & $(1,51)$ & 3,16 & $(1,57)$ \\
Keterhubungan & 3.82 & $(3.83)$ & 3,47 & $(1,59)$ & 3,37 & $(2,10)$ \\
Ketakutan & 3.17 & $(1,40)$ & 3,17 & $(1,80)$ & 2,50 & $(1,66)$ \\
Kebahagiaan & 3,65 & $(1,84)$ & 3,47 & $(1,97)$ & 4,12 & $(2,27)$ \\
Kedamaian & 1.39 & $(0,72)$ & 1,56 & $(1,23)$ & 1,58 & $(1,01)$ \\
Rileks & 1,65 & $(1,19)$ & 1,52 & $(0.89)$ & 2,00 & $(1,66)$ \\
Reflektivitas & 2,65 & $(1,64)$ & 1,82 & $(1,43)$ & 2,08 & $(1,69)$ \\
Sedih & 2,95 & $(1,77)$ & 2,56 & $(1,64)$ & 2,37 & $(1,88)$ \\
Tegang & 3,00 & $(2.00)$ & 2,13 & $(1,42)$ & 3.37 & 2,03 \\
\hline & 4,13 & $(1,66)$ & 4,34 & $(1,74)$ & 4,33 & $(2,23)$ \\
\hline
\end{tabular}

Hipotesis III

Pengujian hubungan antara emosi yang dirasakan dengan penilaian moral yang muncul setelah menonton tayangan film (bukan dipengaruhi musik) dilakukan untuk membuktikan hipotesis 3. Dari semua jenis emosi, penilaian moral yang muncul setelah menonton tayangan film berhubungan dengan agresi ( $r s=0,263, p<0.05)$, keterhubungan ( $r s=0,249, p<0.05)$, kebahagiaan $(r s=0,262, p<0.05)$, reflektivitas (reflectiveness) ( $r s=0,284, p<0.05)$, sedih ( $r s=0,272, p<0.05)$ dan tegang ( $r s=0,269, p<0.05)$. Rata-rata kekuatan hubungan tergolong lemah dengan reflectiveness yang memiliki hubungan paling besar di antara yang lainnya.

Sebagai tambahan, ditelaah korelasi antara kelima fondasi moral dengan penilaian moral. Tidak ada dari kelima fondasi moral yang berhubungan dengan penilaian moral ( $p>0.05$ ). Dengan demikian fondasi moral yang dimiliki partisipan sebagai individu tidak berkaitan dengan penilaian moral dalam 
eksperimen ini. Selain itu, diuji hubungan antara fondasi moral care/harm dengan emosi yang muncul dalam eksperimen. Tidak ada satupun jenis emosi yang berhubungan dengan fondasi moral care/harm $(\mathrm{p}>0.05)$. Purity/Sanctity berhubungan secara negatif dengan ketakutan $(r s=-0,259)$ dan ketegangan ( $r s=-0,326)$ serta berhubungan secara positif dengan kedamaian $(r s=0,251)$ dan reflektivitas $(r s=$ $0,262$ ). Fondasi moral fairness / reciprocity berhubungan secara positif dengan kedamaian ( $r s=0,279)$ dan secara negatif dengan ketakutan ( $r s=-0,307$ ) dan ketegangan ( $r s=-0,270$ ). Sementara itu, authority / respect berhubungan secara positif dengan reflektivitas ( $r s=0,343$ ) dan secara negatif dengan ketakutan ( $r s=-0,332)$.

\section{Pembahasan}

Sebagaimana penelitian Steffens (2018), penelitian ini berupaya menjawab pertanyaan bahwa apakah emosi dan penilaian moral atas tindakan yang digambarkan dalam film dapat dipicu oleh musik latar? Secara umum, meskipun dengan jenis pengujian yang berbeda, temuan eksperimen ini mendukung temuan Steffens bahwa emosi dapat dipicu oleh manipulasi musik yang juga mempengaruhi penilaian moral. Emosi yang dimodulasi oleh musik latar juga berhubungan dengan penilaian moral. Meskipun demikian, secara khusus terdapat perbedaan-perbedaan temuan.

Dalam penelitian ini, jenis musik tidak mempengaruhi emosi dan penilaian moral terhadap cuplikan film, kecuali pada partisipan yang menggunakan headphone. Pada kasus khusus tersebut, manipulasi musik berhubungan dengan rileks dan reflectiveness yang dirasakan, juga penilaian moral terhadap tayangan film. Adanya pengaruh musik ini sejalan dengan penelitian-penelitian yang telah dijelaskan di bagian awal. Selain itu, adanya pengaruh dari penggunaan perangkat audio dapat menunjukkan bahwa intensitas musik ataupun kualitas suara dari musik dapat menjadi salah satu penentu keberhasilan dalam studi-studi tentang emosi yang diinduksi musik.

Meskipun demikian, tidak adanya pengaruh musik pada keseluruhan sampel pada eksperimen ini dapat dikarenakan oleh beberapa hal. Gunawan (2006) menjelaskan bahwa teknik induksi ternyata sangat tergantung kepada sugestibilitas orang yang akan diinduksi. Tipe orang-orang dapat berupa tipe fisik, emosional, dan juga intelektual. Penelitian ini memang memfokuskan pada induksi emosional; kemungkinan ada beberapa orang dengan tipe yang lain yang tidak dapat mengikuti alur induksi sehingga hasil penelitiannya tidak seperti yang diharapkan. Penelitian terkait yang dilakukan oleh Pavlović dan Marković (2011) menunjukkan bahwa informasi visual (film) memiliki efek yang lebih besar pada penilaian emosi daripada informasi auditori (musik). Kondisi ini bisa terjadi secara tidak terprediksi dalam eksperimen ini, sehingga tidak menghasilkan perbedaan emosi dan penilaian moral. Efek modulasi latar belakang musik terhadap emosi juga tergantung pada kualitas emosi seseorang dan mediumnya (Pavlovic \& Markovic, 2011). Spesifikasi adaptif dan fungsional dari emosi-emosi yang berinteraksi seperti nada hedonis, gairah, dan respon perilaku menentukan arah dan intensitas efek induksi musik (Pavlovic \& Markovic, 2011). Efek terhadap emosi juga tergantung pada medium; dalam penelitian ini cuplikan film dan jenis musik bahkan penggunaan perangkat audio bisa menjadi medium.

Suasana hati juga dapat menjadi sesuatu yang berpengaruh terhadap keberhasilan induksi emosi melalui manipulasi musik. Keadaan suasana hati yang positif atau negatif pada individu, yang tidak disebabkan oleh apa pun yang dilakukan oleh peneliti atau orang lain, juga dapat menyebabkan penilaian baik positif maupun negatif terhadap objek tertentu/orang lain. Dalam penelitian ini, pengecekan terhadap kondisi suasana hati partisipan tidak dilakukan sehingga kondisi suasana hati partisipan berbeda-beda. Kondisi suasana hati ini bisa saja berpengaruh terhadap emosi dan penilaian 
moral, bukan karena induksi musik latar.

Dalam hal pengaruh manipulasi musik terhadap penilaian moral, emosi dapat menjadi mediator (Steffens, 2018). Olehnya itu, jika manipulasi musik tidak mempengaruhi emosi maka penilaian moral juga tidak terpengaruh. Pada kasus partisipan yang menggunakan headphone dari penelitian ini, reflectiveness berbeda di antara ketiga kelompok dan ada hubungan antara reflectiveness tersebut dengan penilaian moral. Hal ini dapat berarti bahwa ada kemungkinan musik mempengaruhi penilaian moral melalui reflectiveness. Reflectiveness dikaitkan dengan ketenangan, pemikiran mendalam dan dapat dipicu oleh adegan-adegan dalam cuplikan film yang mengajak penonton untuk mempertimbangkan moral tentang kebenaran tindakan aktor dalam film yang digunakan. Berkaitan dengan rileks yang juga menunjukkan perbedaan antara ketiga kelompok, Malakoutikha dkk. (2020) menemukan bahwa genre musik yang berbeda dapat menurunkan kecemasan dan meningkatkan relaksasi. Penelitian Ugras dkk. (2018) juga menunjukan bahwa semua jenis musik memiliki efek dalam mengurangi kecemasan pasien sebelum operasi.

Selanjutnya, agresi, keterhubungan, kebahagiaan, reflektivitas (reflectiveness), sedih, dan tegang berhubungan dengan penilaian moral. Hal ini memperkuat temuan Seidel dan Printz (2013b) serta penelitian lainnya yang dijelaskan sebelumnya bahwa ada hubungan yang kuat antara emosi tertentu dengan penilaian moral. Emosi merupakan reaksi penilaian (positif atau negatif) yang kompleks dari sistem saraf seseorang terhadap rangsangan dari luar atau dari dalam diri sendiri, sehingga situasi/keadaan individu pada saat mendapatkan rangsangan juga dapat mempengaruhi individu dalam penilaian kebenaran moral suatu tindakan.

Dalam eksperimen ini, beberapa fondasi moral memiliki keterkaitan dengan emosi yang dirasakan, yaitu purity/sanctity, fairness / reciprocity, authority/respect. Purity/Sanctity merupakan fondasi yang mendasari gagasan religius untuk berjuang hidup melalui cara yang lebih tinggi dan mulia, tidak terlalu duniawi. Fondasi ini mendasari gagasan bahwa tubuh seperti kuil yang dapat dinodai oleh kegiatan tidak bermoral. Fairness / reciprocity adalah fondasi yang berkaitan dengan proses evolusi altruisme timbal balik, menghasilkan ide-ide keadilan, hak, dan otonomi. Authority / respect adalah fondasi moral yang dibentuk oleh sejarah interaksi sosial hierarkis, mendasari kebajikan kepemimpinan dan pengikut, termasuk penghormatan kepada otoritas yang sah dan menghormati tradisi (Graham dkk., 2011).

Penelitian Steffens (2018) juga menunjukkan adanya keterkaitan beberapa fondasi moral yang digunakan dalam menilai keputusan moral dengan jenis emosi tertentu, misalnya semakin banyak penilaian seseorang didasarkan pada Harm/Care, semakin banyak emosi takut, ketegangan, reflektivitas dan kesedihan yang dipicu saat menonton kutipan film. Demikian juga, harm/care berhubungan negatif dengan relaksasi dan kedamaian. Akhirnya, semakin banyak partisipan melaporkan bahwa penilaian mereka didasarkan pada purity/sanctity, semakin banyak agresi, kemarahan, ketakutan dan ketegangan yang diinduksi. Berbeda dengan penemuan dalam riset ini, ketiga fondasi moral yang dijelaskan sebelumnya umumnya berhubungan negatif dengan ketakutan dan ketegangan. Meskipun demikian, hasil ini memerlukan penelitian lebih lanjut. Terkait fondasi moral, penelitian Zhang, Kong dan Li (2017) juga menemukan bahwa kesulitan dalam regulasi emosi dapat secara signifikan memprediksi penilaian amoral dalam lima domain fondasi moral, yang mana valensi emosi serta gairah dimediasi oleh efek dalam domain Harm, Fairness and Sanctity.

Hasil penelitian ini dapat berimplikasi pada penggunaan pengaturan jenis musik tertentu untuk tujuan tertentu, dalam hal ini mengarahkan sikap, penilaian bahkan kecenderungan berperilaku. 
Misalnya, memadukan tayangan video dengan musik yang bertujuan untuk mempengaruhi emosi dan penilaian moral, yang diarahkan untuk menggerakkan seseorang melakukan perilaku pro-sosial. Hal ini lebih lanjut diarahkan untuk menumbuhkan kesadaran masyarakat tentang dampak negatif dari persoalan-persoalan tertentu seperti persoalan lingkungan dan pelanggaran HAM. Penggunaan latar belakang musik untuk tayangan video juga dapat diaplikasikan dalam iklan layanan masyarakat maupun iklan produk untuk tujuan komersial.

Berbagai limitasi penelitian ini diidentifikasi untuk kemudian diminimalkan dalam riset-riset selanjutnya. Dalam penelitian ini, film dan adegan yang dipilih tidak sempat diujicobakan bersama alternatif film dan adegan lain sehingga tidak ada pengujian validitas film dan adegan di kalangan experts (minimal dari pihak yang belajar psikologi) untuk menentukan film dan adegan mana yang dianggap paling sesuai. Rangsangan musik yang dipilih juga belum diuji dan divalidasi secara empiris. Selain itu, resolusi video yang diunggah ke dalam google form relatif kecil sehingga beberapa partisipan menyatakan hal itu mempengaruhi perhatiannya. Durasi cuplikan film dan musik latarnya dalam penelitian ini juga masih dianggap singkat oleh beberapa partisipan sehingga kemungkinan memang belum cukup untuk memunculkan emosi. Beberapa partisipan mengaku bahwa ketika menonton, film terasa menggantung dan menimbulkan tanda tanya. Narasi pendek yang mengiringi film juga kurang sesuai dengan representasi isi filmnya. Meskipun demikian, narasi film sengaja dibuat senetral mungkin sehingga tidak mempengaruhi kecenderungan penilaian moral partisipan. Selanjutnya, eksperimen ini tidak didahului oleh pengukuran kondisi emosi partisipan ataupun pemberian stimulus di awal (seperti mendengarkan musik lain) dalam upaya menyamakan kondisi emosi (pengkondisian). Hal yang menjadi perhatian utama, eksperimen ini dilakukan secara online sehingga tidak dapat mengontrol faktor-faktor internal maupun eksternal yang dirasakan/dilakukan oleh responden yang dapat mempengaruhi hasil penelitian, termasuk kesediaan mental dalam mengikuti eksperimen.

Eksperimen ini dapat direplikasi kembali untuk dilakukan dalam seting laboratorium sehingga beberapa variabel bisa dikontrol seperti besarnya resolusi layar, penggunaan headphone dan pengecekan kondisi suasana hati. Beberapa film yang dipilih dapat diujicobakan terlebih dahulu untuk melihat film yang lebih menunjukkan ambiguitas moral. Rangsangan musik yang dipilih pun sebaiknya yang sudah teruji dan tervalidasi. Selain musik, alur cerita yang jelas juga merupakan salah satu faktor yang memunculkan emosi tertentu ketika menonton film. Oleh karena itu, diperlukan film yang secara jelas menunjukkan dialog tentang moral ambigu sehingga narasi pengantar tidak perlu lagi diberikan, untuk mengurangi efek bias pada penilaian moral responden. Dalam rangka memperoleh hasil yang lebih signifikan dengan pengujian yang lebih akurat, penelitian selanjutnya dapat dilakukan pada ukuran sampel yang lebih besar.

\section{Kesimpulan}

Hasil dari studi ini menunjukkan bahwa jenis musik positif dan negatif yang diberikan tidak memberikan pengaruh pada semua jenis emosi yang dirasakan. Artinya, musik latar yang dipilih tidak dapat memunculkan emosi, kecuali pada partisipan yang menggunakan headphone. Pada kasus tersebut, terdapat perbedaan rileks dan reflectiveness yang dirasakan, hal ini dapat berkaitan dengan ritme musik itu sendiri. Jenis musik positif (musik pelan dan melankolis) dan negatif (musik cepat dan penuh tekanan) juga tidak mempengaruhi penilaian moral terkait benar atau salahnya suatu adegan dalam film, kecuali pada kasus khusus ketika hanya peserta yang menggunakan headphone yang dilibatkan dalam analisis. Selanjutnya, terdapat hubungan beberapa jenis emosi dengan penilaian 
moral terhadap tindakan dalam adegan film, antara lain agresi, keterhubungan, kebahagiaan, reflektivitas (reflectiveness), sedih, dan tegang. Reflectiveness bisa ditelaah lebih lanjut sebagai mediator hubungan antara musik dan penilaian moral. Tiga dari lima aspek fondasi moral (MFQ) juga berhubungan secara negatif dengan rasa takut, yaitu purity/sanctity, fairness / reciprocity, dan authority / respect. Aspek purity/sanctity dan fairness / reciprocity secara positif berhubungan dengan kedamaian, sementara authority / respect berkaitan dengan reflektivitas.

\section{Daftar Pustaka}

Avise, J. C., \& Ayala, F. J. (2010). The Difference of Being Human: Morality. Dalam In the Light of Evolution: Volume IV: The Human Condition. National Academies Press (US). https://www.ncbi.nlm.nih.gov/books/NBK210003/

Avramova, Y. R., \& Inbar, Y. (2013). Emotion and moral judgment. WIREs Cognitive Science, 4(2), 169178. https://doi.org/10.1002/wcs.1216

Beer, A., \& Greitemeyer, T. (2019). The effects of background music on tipping behavior in a restaurant: A field study. Psychology of Music, 47(3), 444-450.

https://doi.org/10.1177/0305735618755887

Brodsky, W., Olivieri, D., \& Chekaluk, E. (2018). Music genre induced driver aggression: A case of media delinquency and risk-promoting popular culture. Music \& Science, 1, 205920431774311. https://doi.org/10.1177/2059204317743118

Capraro, V., Jordan, J. J., \& Tappin, B. M. (2021). Does observability amplify sensitivity to moral frames? Evaluating a reputation-based account of moral preferences. Journal of Experimental Social Psychology, 94, 104103. https://doi.org/10.1016/j.jesp.2021.104103

Cohen, A. J. (2001). Music as a source of emotion in film. Music and emotion: Theory and research, 249-272.

Critcher, C. R., Helzer, E. G., \& Tannenbaum, D. (2020). Moral character evaluation: Testing another's moral-cognitive machinery. Journal of Experimental Social Psychology, 87, 103906. https://doi.org/10.1016/j.jesp.2019.103906

Cushman, F., Young, L., \& Greene, J. D. (2010). Multi-system Moral Psychology. Dalam The Moral Psychology Handbook. Oxford University Press.

https://www.oxfordscholarship.com/view/10.1093/acprof:oso/9780199582143.001.0001/acprof9780199582143-chapter-3

Feinberg, M., Willer, R., Antonenko, O., \& John, O. P. (2012). Liberating reason from the passions: Overriding intuitionist moral judgments through emotion reappraisal. Psychological science, 23(7), 788-795.

Fischer, P., \& Greitemeyer, T. (2006). Music and Aggression: The Impact of Sexual-Aggressive Song Lyrics on Aggression-Related Thoughts, Emotions, and Behavior Toward the Same and the Opposite Sex. Personality and Social Psychology Bulletin, 32(9), 1165-1176.

https://doi.org/10.1177/0146167206288670 
Graham, J., Nosek, B. A., Haidt, J., Iyer, R., Koleva, S., \& Ditto, P. H. (2011). Mapping the moral domain. Journal of Personality and Social Psychology, 101(2), 366-385. https://doi.org/10.1037/a0021847

Greene, J., \& Haidt, J. (2002). How (and where) does moral judgment work? Trends in Cognitive Sciences, 6(12), 517-523. https://doi.org/10.1016/S1364-6613(02)02011-9

Greitemeyer, T. (2009). Effects of Songs With Prosocial Lyrics on Prosocial Behavior: Further Evidence and a Mediating Mechanism. Personality and Social Psychology Bulletin, 35(11), 1500-1511. https://doi.org/10.1177/0146167209341648

Gross, J. J. (2013). Handbook of emotion regulation. Guilford publications.

Gunawan, A. W. (2006). Hypnosis: The Art of Subconscious Communication. Jakarta: Gramedia Pustaka Utama.

Haidt, J. (2001). The Emotional Dog and Its Rational Tail: A Social Intuitionist Approach to Moral Judgment. 108, 21.

Haidt, J., \& Graham, J. (2007). When Morality Opposes Justice: Conservatives Have Moral Intuitions that Liberals may not Recognize. Social Justice Research, 20(1), 98-116. https://doi.org/10.1007/s11211-007-0034-z

Juslin, P. N., \& Laukka, P. (2004). Expression, Perception, and Induction of Musical Emotions: A Review and a Questionnaire Study of Everyday Listening. Journal of New Music Research, 33(3), 217-238. https://doi.org/10.1080/0929821042000317813

Kämpfe, J., Sedlmeier, P., \& Renkewitz, F. (2011). The impact of background music on adult listeners: A meta-analysis. Psychology of Music, 39(4), 424-448. https://doi.org/10.1177/0305735610376261

Kopiez, R., Platz, F., \& Wolf, A. (2013). The overrated power of background music in television news magazines: A replication of Brosius' 1990 study. Musicae Scientiae, 17(3), 309-331. https://doi.org/10.1177/1029864913489703

Lee, J. J., \& Gino, F. (2015). Poker-faced morality: Concealing emotions leads to utilitarian decision making. Organizational Behavior and Human Decision Processes, 126, 49-64.

Lipscomb, S. D., \& Tolchinsky, D. E. (2005). The role of music communication. Musical communication, 383.

Malakoutikhah, A., Dehghan, M., Ghonchehpoorc, A., Parandeh Afshar, P., \& Honarmand, A. (2020). The effect of different genres of music and silence on relaxation and anxiety: A randomized controlled trial. EXPLORE, S1550830720300860. https://doi.org/10.1016/j.explore.2020.02.005

Palazzi, A., Wagner Fritzen, B., \& Gauer, G. (2019). Music-induced emotion effects on decisionmaking. Psychology of Music, 47(5), 621-643. https://doi.org/10.1177/0305735618779224

Pavlovic, I., \& Markovic, S. (2011). The effect of music background on the emotional appraisal of film sequences. Psihologija, 44(1), 71-91. https://doi.org/10.2298/PSI1101071P

Pecorino, P. (2006). The Basis for Morality. 
https://www.qcc.cuny.edu/socialsciences/ppecorino/ciseshv_text/Chapter-3-Ethics/ch-3-Basisfor-Morality.html

Seidel, A., \& Prinz, J. (2013a). Sound morality: Irritating and icky noises amplify judgments in divergent moral domains. Cognition, 127(1), 1-5. https://doi.org/10.1016/j.cognition.2012.11.004

Seidel, A., \& Prinz, J. (2013b). Mad and glad: Musically induced emotions have divergent impact on morals. Motivation and Emotion, 37(3), 629-637. https://doi.org/10.1007/s11031-012-9320-7

Septianto, F., Tjiptono, F., \& Kusumasondjaja, S. (2020). Anger punishes, compassion forgives: How discrete emotions mitigate double standards in consumer ethical judgment. Journal of Retailing and Consumer Services, 53, 101979. https://doi.org/10.1016/j.jretconser.2019.101979

Steffens, J. (2018). The influence of film music on moral judgments of movie scenes and felt emotions. Psychology of Music, 48(1), 3-17. https://doi.org/10.1177/0305735618779443

Szekely, R. D., \& Miu, A. C. (2015). Incidental emotions in moral dilemmas: The influence of emotion regulation. Cognition and Emotion, 29(1), 64-75. https://doi.org/10.1080/02699931.2014.895300

Uğraş, G. A., Yıldırım, G., Yüksel, S., Öztürkçü, Y., Kuzdere, M., \& Öztekin, S. D. (2018). The effect of different types of music on patients' preoperative anxiety: A randomized controlled trial. Complementary Therapies in Clinical Practice, 31, 158-163. https://doi.org/10.1016/j.ctcp.2018.02.012

Vitouch, O. (2016). When Your Ear Sets the Stage: Musical Context Effects in Film Perception: Psychology of Music. https://doi.org/10.1177/0305735601291005

Yi, F., \& Kang, J. (2019). Effect of background and foreground music on satisfaction, behavior, and emotional responses in public spaces of shopping malls. Applied Acoustics, 145, 408-419. https://doi.org/10.1016/j.apacoust.2018.10.029

Zhang, L., Kong, M., \& Li, Z. (2017). Emotion regulation difficulties and moral judgment in different domains: The mediation of emotional valence and arousal. Personality and Individual Differences, 109, 56-60. https://doi.org/10.1016/j.paid.2016.12.049

Ziv, N., Hoftman, M., \& Geyer, M. (2012). Music and moral judgment: The effect of background music on the evaluation of ads promoting unethical behavior. Psychology of Music, 40(6), 738-760. https://doi.org/10.1177/0305735611406579 